Published in final edited form as:

J Med Chem. 2007 June 14; 50(12): 2779-2786.

\title{
Design, Synthesis, and Biological Evaluation of Novel Bifunctional C-Terminal-Modified Peptides for $\delta / \mu$ Opioid Receptor Agonists and Neurokinin-1 Receptor Antagonists
}

\author{
Takashi Yamamoto $\dagger$, Padma Nair ${ }^{\dagger}$, Peg Davis $\ddagger$, Shou-wu Ma $\ddagger$, Edita Navratilova $\ddagger$, Sharif \\ Moye ${ }^{\ddagger}$, Suneeta Tumati ${ }^{\ddagger}$, Josephine Lai ${ }^{\ddagger}$, Todd W. Vanderah ${ }^{\ddagger}$, Henry I. Yamamura ${ }^{\ddagger}$, Frank \\ Porreca $¥$, and Victor J. Hruby ${ }^{*}, \dagger$ \\ Departments of Chemistry, and Pharmacology, University of Arizona, Tucson, Arizona 85721
}

$\dagger$ Department of Chemistry, University of Arizona, Tucson, AZ 85721.

$\$$ Department of Pharmacology, University of Arizona, Tucson, AZ 85724.

\begin{abstract}
A series of bifunctional peptides that act as agonists for $\delta$ and $\mu$ opioid receptors with $\delta$ selectivity and as antagonist for neurokinin-1 (NK1) receptors were designed and synthesized for potential application as analgesics in various pain states. The peptides were characterized using radioligand binding assays and functional assays using cell membrane and animal tissue. Optimization was performed on the fifth residue which serves as an address moiety for both receptor recognitions. It had critical effects on both activities at $\delta / \mu$ opioid receptors and NK1 receptors. Among the synthesized peptides, H-Tyr-D-Ala-Gly-Phe-Met-Pro-Leu-Trp-O-3,5-Bzl $\left(\mathrm{CF}_{3}\right)_{2}(\mathbf{5})$ and H-Tyr-DAla-Gly-Phe-Nle-Pro-Leu-Trp-O-3,5-Bzl $\left(\mathrm{CF}_{3}\right)_{2}(7)$ had excellent agonist activity for both $\delta$ opioid and $\mu$ opioid receptors and excellent antagonist activity for NK1 receptors. These results indicate that the rational design of multifunctional ligands with opioid agonist and neurokinin-1 antagonist activities can be accomplished and may provide a new tool for treatment of chronic and several pain states.
\end{abstract}

\section{Introduction}

Opioids remain the most important analgesics in the treatment of severe acute pain and play a significant role in the treatment of chronic pain states as well. Opioid agonists produce potent analgesia through the activation of seven transmembrane $\mathrm{G}$ protein-coupled receptors (termed $\delta, \mu$, and $\kappa$ opioid receptors). ${ }^{1}$ It is well-known that the 11 -amino acid peptide substance $\mathrm{P}$ acts as an excitatory and pronociceptive neurotransmitter of the pain signaling through the neurokinin-1 (NK1) ${ }^{\mathrm{a}}$ receptor. Even though highly specific antagonists of the NK1 receptor failed to show significant analgesic efficacy in clinical trials, ${ }^{2,3}$ substance $P$ is believed to play a role in chronic inflammatory pain states by contributing to the establishment of central

\footnotetext{
*To whom correspondence should be addressed. Tel: (520)-621-6332, Fax: (520)-621-8407, E-mail: hruby@u.arizona.edu.. Supporting Information Available: ${ }^{1} \mathrm{H}$ NMR data. This material is available free of charge via the Internet at http://pubs.acs.org. aAbbreviations: AcOH, acetic acid; Boc, tert-butyloxycarbonyl; $\mathrm{BuOH}$, butanol; Bzl, benzyl; BSA, bovine serum albumin; CCK, cholecystokinin; $\mathrm{CHO}$, Chinese hamster ovary; DMEM, Dulbecco's modified Eagle's medium; DMF, $N, N$-dimethylformamide; DMSO, dimethyl sulfoxide; DOR, $\delta$ opioid receptor; DPDPE, c[D-Pen ${ }^{2}$, D-Pen ${ }^{5}$ ]enkephalin; DAMGO, [D-Ala ${ }^{2}, \mathrm{NMePhe}^{4}$, Gly ${ }^{5}$-ol]enkephalin; EtOAc, ethyl acetate; ESI, electrospray ionization; GPCR, G-protein-coupled receptor; GPI, guinea pig-isolated ileum; HEK, human embryonic kidney; HOBt, 1-hydroxybenzotriazole; HRMS, high-resolution mass spectroscopy; i.th., intrathecal; LMMP, longitudinal muscle with myenteric plexus; MOR, $\mu$ opioid receptor; MVD, mouse vas deferens; NK1, neurokinin-1; NMM, $N$-methylmorpholine; RP-HPLC, reverse phase high performance liquid chromatography; PyBOP, benzotriazol-1-yl-oxytripyrrolidinophosphonium hexafluorophosphate; SAR, structure-activity relationships; SEM, mean standard error; TFA, trifluoroacetic acid; Trp-O-3,5-Bzl $\left(\mathrm{CF}_{3}\right)_{2}, 3^{\prime}, 5^{\prime}$-(bistrifluoromethyl)-benzyl ester of tryptophan.
} 
sensitization and consequent hyperalgesia. ${ }^{4-7}$ Interestingly, the coadministration of opioid agonists and substance $\mathrm{P}$ antagonists showed enhanced antinociceptive potency in acute pain states and in prevention of opioid-induced tolerance in chronic preclinical trials. ${ }^{8-13}$ These results suggested that contributions from pronociceptive signaling through the NK1 receptor can play a significant role in the outcome of analgesic actions of opioids acting at opioid receptors. Such interactions of pro- and antinociceptive activity may have an anatomical basis as the expression of the NK1 and opioid receptors as well as the neurotransmitters show a significant degree of overlap in the central nervous system. ${ }^{12,14-16}$

In view of these findings, we have designed novel chimeric molecules in which structural moieties for both $\delta / \mu$ opioid agonists and NK1 antagonists were included. These chimeric peptides should be easier to administer and have lower risk of drug-drug interactions than coadministration of two different drugs and are expected to have enhanced and concerted antinociceptive potency without the development of analgesic tolerance. The novel concept of designing dual-pharmacophore molecules has been successfully developed in our group mainly with the analgesic peptides targeting to both $\delta / \mu$ opioid receptors and cholecystokinin (CCK) receptors. ${ }^{17-20}$

To date, some molecules are already reported to have both $\delta / \mu$ opioid agonist and substance $\mathrm{P}$ antagonist activities. ${ }^{21-23}$ However, their activities are biased for one of the receptors, and no molecule had sufficient and balanced activities for both of opioid and NK1 receptors. Therefore, we have designed and synthesized bifunctional molecules possessing agonist activities at both $\delta / \mu$ opioid receptors and NK1 receptor antagonist activities. Consideration of $\delta / \mu$ selectivity for opioid receptors suggests that $\mu$ opioid receptor agonists such as morphine have higher antinociceptive activity which also is associated with higher abuse liability and other side effects. On the other hand, the activation of $\delta$ opioid receptors has lower analgesic efficacy but also has reduced addictive potential. ${ }^{3,24}$ In order to reduce the undesired adverse effects of opioids, higher potency at $\delta$ opioid receptors than at $\mu$ opioid receptors should be preferable. ${ }^{25-28}$ According to these considerations, we chose H-Tyr-o-Ala-Gly-Phe sequence for the opioid agonist part which is a substituted "message" sequence of enkephalins (H-TyrGly-Gly-Phe) but with the second amino acid being ${ }_{\mathrm{D}}$-Ala. This sequence has higher metabolic stability 29 and has been used in several potent opioids including the $\delta$ selective agonist DADLE and the superpotent $\delta / \mu$ dual agonist biphalin (Figure 1). ${ }^{24,30}$ As for the NK1 receptor antagonist part, the moiety from the $3^{\prime}, 5^{\prime}$ - (bistrifluoromethyl)-benzyl ester of $\mathrm{N}$-acylated tryptophans was chosen (Figure 1). ${ }^{31-34}$ Modeling studies revealed that the two aromatic groups of L-732,138 (Ac-Trp-O-3,5-Bzl $\left.\left(\mathrm{CF}_{3}\right)_{2}\right)$, which is one of the most thoroughly studied $3^{\prime}, 5^{\prime}$-(bistrifluoromethyl)-benzyl esters of $\mathrm{N}$-acylated tryptophans, binds to $\mathrm{His}^{197}$ and His $^{265}$ of human NK1 receptors and bulky substituents seemed to be tolerated on the N-terminal acetyl moiety. ${ }^{32}$ In fact, the derivative Cbz-Pro-Leu-Trp-O-3,5-Bzl( $\left(\mathrm{CF}_{3}\right)_{2}$, which has two more amino acids capped with a Cbz group at the $\mathrm{N}$-terminus, maintains good affinity for NK1 receptors. ${ }^{33-34}$ Thinking about the reported SAR, the Cbz-Pro-Leu sequence seems to have a positive influence on antagonistic activity at the NK1 receptor, ${ }^{33-34}$ and the Cbz group has structural similarities to $\mathrm{a}_{\mathrm{L}}$ - or $\mathrm{D}$-phenylalanine. According to these considerations, we decided to use Phe-Pro-Leu-Trp-O-3,5-Bzl( $\left(\mathrm{CF}_{3}\right)_{2}$ or -Phe-Pro-Leu-Trp-O-3,5-Bzl $\left(\mathrm{CF}_{3}\right)_{2}$ as our NK1 receptor antagonist structural moiety. Here, we report a successful design and structure-activity relationship study of bifunctional peptides which combine these two sequences.

\section{Results and Discussion}

\section{Synthesis}

The bifunctional peptides were synthesized using stepwise solution-phase PyBOP/HOBtchemistry (Figure 2). The synthesis was started from the coupling reaction of Boc-Pro-Leu$\mathrm{OH}$ and tryptophan $3^{\prime}, 5^{\prime}$-(bistrifluoromethyl)-benzyl ester hydrochloride followed by 
deprotection of the Boc group using $4 \mathrm{M}$ hydrogen chloride in 1,4-dioxane. ${ }^{33-34}$ After subsequen chain elongation, we obtained the $3^{\prime}, 5^{\prime}$-(bistrifluoromethyl)-benzyl ester of the pentapeptide structure which was coupled with Boc-Tyr-D-Ala-Gly-OH. The final crude peptides were obtained upon treatment of trifluoroacetic acid to remove the protecting groups. Peptide intermediates were isolated by precipitation from cold ether or petroleum ether, and the obtained final crude peptides were purified by RP-HPLC to give pure (>98\%) peptides. The final peptides were characterized and their purity confirmed by analytical HPLC, ${ }^{1} \mathrm{H}$ NMR, HRMS, and TLC (Table 1). ${ }^{1} \mathrm{H}$ NMR studies showed that cis/ trans isomerization at the Pro ${ }^{6}$ residue was found in some of the synthesized peptides. The ratio of two amide rotamers and their assignments are available in the Supporting Information.

\section{Structure-Activity Relationships}

The opioid receptor binding affinities of the synthesized bifunctional peptides were evaluated using human $\delta$-opioid receptors (hDOR) and rat $\mu$-opioid receptors (rMOR) with cells that stably express these receptors as previously described (Table 2). ${ }^{18,20,35,36}\left[{ }^{3} \mathrm{H}\right] \mathrm{DPDPE}$ and $\left[{ }^{3} \mathrm{H}\right] \mathrm{DAMGO}$ were used as their radioligands, respectively. Their agonistic efficacies were determined at the level of receptor G-protein interaction measuring agonist stimulated binding of the GTP analogue guanosine-5'-O-(3-[ $\left.{ }^{35} \mathrm{~S}\right]$ thio)-triphosphate $\left(\left[{ }^{35} \mathrm{~S}\right] \mathrm{GTP} \gamma\right)$ on the same transfected cells as the binding affinities assays (Table 3). $18,20,35,36$ The tissue bioassays (mouse vas deferens: MVD, guinea pig isolated ileum: GPI) also were performed to characterize agonist function at $\delta$ and $\mu$ opioid receptors as described previously (Table 4). $18,20,35,36$ As for their affinity for the rat NK1 (rNK1) receptor, receptor binding assays also were used on transfected Chinese hamster ovary $(\mathrm{CHO})$ cells that stably express rNK1 receptors using $\left[{ }^{3} \mathrm{H}\right]$-substance $\mathrm{P}$ as the standard radioligand (Table 2). To estimate their antagonistic activities against substance $\mathrm{P}$ stimulation, tissue bioassays using the guinea pig ileum (GPI) were performed in the presence of naloxone. All the synthesized peptides were confirmed to have no or negligible agonist activities against substance P stimulation (Table 4).

On the basis of the rational design described above, we first tested two peptides, $\mathrm{H}-\mathrm{Tyr}$-D-AlaGly-Phe-Phe-Pro-Leu-Trp-O-3,5-Bzl( $\left(\mathrm{CF}_{3}\right)_{2}(\mathbf{1})$ and H-Tyr-d-Ala-Gly-Phe-o-Phe-Pro-LeuTrp-O-3,5-Bzl $\left(\mathrm{CF}_{3}\right)_{2}(2)$, in which both opioid agonist structure (HTyr-d-Ala-Gly-Phe) and NK1 antagonist moiety (Phe-Pro-Leu-Trp-O-3,5-Bzl $\left(\mathrm{CF}_{3}\right)_{2}$ or D-Phe-Pro-Leu-Trp-O-3,5-Bzl $\left.\left(\mathrm{CF}_{3}\right)_{2}\right)$ were fused into one molecule via simple amide bonds. Interestingly, the binding affinities of 1 at both $\delta / \mu$ opioid receptors were in the $10 \mathrm{nM}$ range $\left(K_{\mathrm{i}}\right) 15 \mathrm{nM}, \delta$ opioid; 28 $\mathrm{nM}, \mu$ opioid) (Table 2). Peptide 1 showed potent $\delta$ and $\mu$ opioid agonist efficacies in the $\left[{ }^{35} \mathrm{~S}\right] \mathrm{GTP} \gamma \mathrm{S}$ binding assays with the $\mathrm{EC}_{50}$ values of 21 and $59 \mathrm{nM}$, respectively (Table 3 ). The binding affinity of $\mathbf{1}$ at rNK1 was very potent with a subnanomolar $K_{\mathrm{i}}$ value $(0.88 \mathrm{nM})$. Moreover, the GPI assay demonstrated that $\mathbf{1}$ acted as an antagonist against substance $\mathrm{P}$ stimulation $\left(K_{\mathrm{e}}=14 \mathrm{nM}\right)$ (Table 4$)$. It should be noted that $\mathbf{1}$ had excellent affinity at rat NK1 receptors as well as good functional activity using guinea pig ileum tissue, which means that 1 had substance $P$ antagonist activities in animal models for both of the species. Moreover, the affinity and bioactivity of $\mathbf{1}$ were greatly improved over those of L-732,138 whose $\mathrm{IC}_{50}$ value for the rNK1 was reported to be around $460 \mathrm{nM}$ in radioligand binding assays ${ }^{32}$ and whose $K_{\mathrm{e}}$ value in GPI tissue was $250 \mathrm{nM}$ (520-fold and 12-fold, respectively). Even though peptide 1 was not very $\delta$ opioid selective, these results clearly demonstrated the success of the rationale of our design. However, the peptide possessing a $\mathrm{D}$-amino acid in position 5 (2) was found to have drastically lower affinities than $1\left(K_{\mathrm{i}}=93 \mathrm{nM}, \delta\right.$ opioid; $380 \mathrm{nM}, \mu$ opioid; $3.0 \mathrm{nM}$, rNK1), which suggested that the amino acid residue in position 5 was critical for binding affinities, and the ${ }_{\mathrm{L}}$-form was preferred over the ${ }_{\mathrm{D}}$-form. It is reasonable to expect position 5 of these peptides to play an important role not only at NK1 receptors, but also at $\delta / \mu$ opioid receptors, since it can act as an "address" element for the NK1 antagonist pharmacophore as well as an "address" region for the opioid receptor. ${ }^{24,25}$ Considering these results, we focused our work 
on optimizing the position 5 of $\mathbf{1}$ to find a bifunctional compound possessing potent substance $\mathrm{P}$ antagonist activity and effective $\delta / \mu$ opioid agonist activities with $\delta$ selectivity. First, Gly which is the simplest amino acid was introduced at position 5 of $\mathbf{1}$ (H-Tyr-D-Ala-Gly-Phe-GlyPro-Leu-Trp-O-3,5-Bzl $\left(\mathrm{CF}_{3}\right)_{2} ; \mathbf{3}$ ). Although the binding assays (Table 2 ) of $\mathbf{3}$ showed lower affinity for $\delta$ opioid receptors $\left(K_{\mathrm{i}}=36 \mathrm{nM}\right)$ than did 1, the affinities at both $\mu$ opioid and rNK1 receptors were maintained $\left(K_{\mathrm{i}}\right) 27, \mu$ opioid; $1.0 \mathrm{nM}$, rNK1). The opioid agonist activities of ligand 3 in the MVD and GPI assays were much higher than expected from the binding assay results but were not greatly improved from the results of $\mathbf{1}\left(\mathrm{IC}_{50}=170\right.$ and $380 \mathrm{nM}$, respectively). The antagonist activity of $\mathbf{3}$ against substance $\mathrm{P}$ stimulation in the GPI tissue assay also was higher than that of $\mathbf{1}\left(K_{\mathrm{e}}=5.4 \mathrm{nM}\right)$. These improvements in tissue assays might indicate that the aromatic side chain at position 5 led to low activity or to metabolical instability, and thus we chose Leu and Met for the next substituents (H-Tyr-o-Ala-Gly-Phe-Leu-Pro-LeuTrp-O-3,5-Bzl- $\left(\mathrm{CF}_{3}\right)_{2} ; 4$ and H-Tyr-- -Ala-Gly-Phe-Met-Pro-Leu-Trp-O-3,5-Bzl $\left.\left(\mathrm{CF}_{3}\right)_{2} ; \mathbf{5}\right)$. In these modifications, the $1-5$ residues of two peptides $\left(\mathrm{H}_{-} \mathrm{Tyr}^{1}{ }^{-\mathrm{D}}-\mathrm{Ala}^{2}-\mathrm{Gly}^{3}-\mathrm{Phe}^{4}-\mathrm{Leu}^{5}\right.$ of 4 and $\mathrm{H}-\mathrm{Tyr}^{1}$-D-Ala ${ }^{2}-\mathrm{Gly}^{3}-\mathrm{Phe}^{4}-\mathrm{Met}^{5}$ of 5 ) were very similar to the endogenous opioid peptides Leuenkephalin (H-Tyr-Gly-Gly-Phe-Leu-OH) and Met-enkephalin (H-Tyr-Gly-Gly-Phe-Met$\mathrm{OH})$, both of which have potent opioid activities as well as $\delta$ receptor selectivity. As can be seen in Table 2, binding affinity at $\delta$ opioid receptors of $\mathbf{4}$ was improved from that of $\mathbf{3}\left(K_{\mathrm{i}}=\right.$ $5.0 \mathrm{nM})$ and its $K_{\mathrm{i}}$ value at $\mu$ opioid receptors was $23 \mathrm{nM}$ with 4.7 -fold $\delta$ receptor selectivity over $\mu$ receptors. The agonist activities of ligand 4 in the $\left[{ }^{35} \mathrm{~S}\right] \mathrm{GTP} \gamma \mathrm{S}$ binding assays showed a similar tendency, with $\mathrm{EC}_{50}$ values of 9.6 and $33 \mathrm{nM}$, respectively (3.4-fold $\delta$ selectivity). This $\delta$ selectivity was maintained in the MVD and GPI assays (3.4-fold). The affinity at rNK1 receptors of 4 was retained relative to $3\left(K_{\mathrm{i}}=0.80 \mathrm{nM}\right)$ with slightly decreased antagonist activity in the GPI assay $\left(\mathrm{IC}_{50}=19.4 \mathrm{nM}\right)$. In the case of peptide $\mathbf{5}$, there was a large increase in $\delta$ opioid activity $\left(K_{\mathrm{i}}=2.8 \mathrm{nM}\right)$, and 13 -fold $\delta$ selectivity was seen over $\mu$ opioid receptors in the binding assays. The agonist activities for both $\delta$ and $\mu$ opioid receptors in $\left[{ }^{35} \mathrm{~S}\right] \mathrm{GTP} \gamma \mathrm{S}$ binding assays were consistent with the results of the binding assays $\left(\mathrm{EC}_{50}=2.9\right.$ and $32 \mathrm{nM}$, respectively). Moreover, ligand $\mathbf{5}$ showed excellent functional opioid agonist activity in the MVD assay $\left(\mathrm{IC}_{50}=22 \mathrm{nM}\right)$ with better selectivity over that of the GPI assay (16-fold). Although the substance $P$ antagonist activity of $\mathbf{5}$ in the GPI assay was less than that of $\mathbf{3}$, it still retained good activity $\left(K_{\mathrm{e}}=25 \mathrm{nM}\right)$ with excellent affinity for $\mathrm{rNK} 1$ receptors $\left(K_{\mathrm{i}}=0.29\right.$ $\mathrm{nM}$ ). Moreover, the $K_{\mathrm{e}}$ value of $\mathbf{5}$ in the GPI assay against substance P stimulation was almost equivalent to its $\mathrm{IC}_{50}$ value in the MVD assay against opioid stimulation. Therefore, we can say that peptide $\mathbf{5}$ is a highly active, highly balanced and good $\delta$ selective bifunctional compound for the $\delta / \mu$ opioid and NK1 receptors. Next, we made further modifications in position 5 based on 5 . Improved activities and $\delta$ selectivity were sought. The oxidized form of ligand 5 at Met, ${ }^{5}$ H-Tyr-b-Ala-Gly-Phe-Met(O)-Pro-Leu-Trp-O-3,5-Bzl $\left(\mathrm{CF}_{3}\right)_{2}(\mathbf{6})$, was synthesized and tested since it has been reported that methionine oxidation enhances opioid activities as well as $\delta$ selectivity for enkephalin analogues. ${ }^{37,38}$ In fact, this modification led to better binding affinity at the $\mu$ opioid receptors than that of $5\left(K_{\mathrm{i}}=5.5 \mathrm{nM}\right)$ but a decreased $K_{\mathrm{i}}$ value at $\delta$ opioid receptors which led to almost equivalent affinities at both $\delta$ and $\mu$ opioid receptors $\left(\delta\right.$ selectivity, 1.1 -fold). As for the $\mathrm{EC}_{50}$ values in the $\left[{ }^{35} \mathrm{~S}\right] \mathrm{GTP} \gamma \mathrm{S}$ binding assays, ligand $\mathbf{6}$ unexpectedly showed the highest agonist activity at $\delta$ opioid receptors with the best $\delta$ selectivity (19-fold). However, this good $\delta$ selectivity was decreased to 4.7 -fold in the MVD and GPI assays ( $\mathrm{IC}_{50}=33$ and $150 \mathrm{nM}$, respectively). The affinity of ligand 6 at rNK1 receptors increased from that of $\mathbf{5}\left(K_{\mathrm{i}}=0.20 \mathrm{nM}\right)$, and its substance P antagonist activity in the GPI assay was also improved $\left(K_{\mathrm{e}}=7.8 \mathrm{nM}\right)$. Nle, which is a general bioisostere of Met, also was introduced at position 5 of the sequence (H-Tyr-o-Ala-Gly-Phe-Nle-Pro-Leu-Trp-O-3,5-Bzl $\left.\left(\mathrm{CF}_{3}\right)_{2} ; 7\right)$. In receptor binding assays, ligand 7 showed the best affinity for $\delta$ opioid receptors $\left(K_{\mathrm{i}}=1.8 \mathrm{nM}\right)$, and its $K_{\mathrm{i}}$ value at $\mu$ opioid receptors was less than $10 \mathrm{nM}(9.8 \mathrm{nM}$; $5.4-$ fold $\delta$ selectivity). In the $\left[{ }^{35} \mathrm{~S}\right] \mathrm{GTP} \gamma \mathrm{S}$ binding assays, the $\delta$ selectivity of 7 was moderate (6.9-fold) just as in the receptor binding assays. However, the $\delta$ selectivity showed a distinct increase in tissue assays (22-fold), in which $\mathrm{IC}_{50}$ value in the MVD assay was the best among all the tested 
ligands $(17 \mathrm{nM})$. The rNK1 affinity of 7 was slightly decreased and substance $\mathrm{P}$ antagonist activity of 7 was increased from that of $5\left(K_{\mathrm{i}}=0.60 \mathrm{nM}\right.$ and $K_{\mathrm{e}}=7.9 \mathrm{nM}$, respectively). Finally, we tested $\mathrm{N}$-methylation of $\mathrm{Nle}^{5}$ of 7 (H-Tyr-D-Ala-Gly-Phe- $N$-Me-Nle-Pro-Leu-Trp-O-3,5$\left.\mathrm{Bzl}\left(\mathrm{CF}_{3}\right)_{2} ; \mathbf{8}\right)$ since a $\delta$ selective and potent enkephalin analogue has been reported with $\mathrm{N}$ methylation at position $5 .{ }^{39-41}$ However, although this modification led to the best substance $\mathrm{P}$ antagonist activity in the functional assay $\left(K_{\mathrm{e}}=4.6 \mathrm{nM}\right)$, ligand $\mathbf{8}$ showed a significant decrease of binding affinities at both $\delta$ and $\mu$ opioid receptors as well as agonist activities in the $\left[{ }^{35} \mathrm{~S}\right] \mathrm{GTP} \gamma \mathrm{S}$ binding assays, with low $\delta$ selectivity (1.8 and 0.4 -fold, respectively). These results show that the introduction of an $N$-methyl amino acid at position 5 decreases the activities not only at opioid receptors but also at rNK1 receptors.

\section{Conclusions}

A series of bifunctional peptides with a modified $C$-terminus in which structural moieties for a $\delta / \mu$ opioid agonist and a NK1 antagonist were fused into one molecule were designed for treatment of pain. Eight analogues were tested in an effort to optimize the fifth residue for better activities at both $\delta / \mu$ opioid and NK1 receptors with $\delta$ opioid selectivity. From the structure-activity relationships study, the residue at position 5, which is the fused position of two structural elements, was found to act as an "address region" for both opioid agonist and NK1 antagonist pharmacophores and have a critical influence on both activities. As a result of this optimization, both peptide 5, H-Tyr-- -Ala-Gly-Phe-Met-Pro-Leu-Trp-O-3,5-Bzl $\left(\mathrm{CF}_{3}\right)_{2}$, and 7, H-Tyr-d-Ala-Gly-Phe-Nle-Pro-Leu-Trp-O-3,5-Bzl $\left(\mathrm{CF}_{3}\right)_{2}$, showed potent activities as an opioid agonist and NK1 antagonist with $\delta$-opioid selectivity and without species differences between rats and guinea pigs. These results strongly supported the rationale for our design of fused structural moieties, and these bifunctional peptides at opioid and NK1 receptors are promising analgesics for treatment of various pain states. ${ }^{56}$ The in vivo study of the bifunctional peptides are ongoing and will be reported elsewhere.

\section{Experimental Section}

\section{Materials}

All amino acid derivatives, $\mathrm{PyBOP}$, and $\mathrm{HOBt}$ were purchased from EMD Biosciences (Madison, WI), Bachem (Torrance, CA), and Chem Impex International (Wood Dale, IL). Myo-[2- $\left.{ }^{3} \mathrm{H}(\mathrm{N})\right]$-inositol; [tyrosyl-3,5- ${ }^{3} \mathrm{H}(\mathrm{N})$ D $_{\mathrm{D}}-\mathrm{Ala}^{2}-\mathrm{Mephe}^{4}$-glyol ${ }^{5}$-enkephalin (DAMGO); [tyrosyl-2,6- $\left.{ }^{3} \mathrm{H}(\mathrm{N})\right]-\left(2\right.$-р-penicillamine, 5 -р-penicillamine) enkephalin (DPDPE); [ $\left.{ }^{3} \mathrm{H}\right]-$ substance $\mathrm{P}$; and $\left[{ }^{35} \mathrm{~S}\right]$-guanosine $5^{\prime}$-( $\gamma$-thio) triphosphate were purchased from Perkin-Elmer (Wellesley, MA). Bovine serum albumin (BSA), protease inhibitors, Tris, and other buffer reagents were obtained from Sigma (St. Louis, MO). Culture medium (MEM, DMEM, and IMDM), Penicillin/streptomycin and fetal calf serum (FCS) were purchased from Invitrogen (Carlsbad, CA).

\section{H-Pro-Leu-Trp-O-3,5-BzI $\left(\mathrm{CF}_{3}\right)_{2} \cdot \mathrm{HCl}$}

Boc-Pro-Leu-OH (2.05 g, $6.41 \mathrm{mmol})$ and H-Trp-O-3,5-Bzl( $\left.\mathrm{CF}_{3}\right)_{2} \cdot \mathrm{HCl}(2.76 \mathrm{~g}, 6.41 \mathrm{mmol})$ $33,34$ were dissolved in DMF (20 mL). HOBt (865 mg, $7.69 \mathrm{mmol})$, PyBOP (3.33 g, 7.69 $\mathrm{mmol})$, and NMM $(1.42 \mathrm{~g}, 14.1 \mathrm{mmol})$ were added to the solution at $0{ }^{\circ} \mathrm{C}$. After stirring overnight at room temperature, saturated aqueous sodium bicarbonate was added to the solution and most of the organic solvent was removed under reduced pressure. The residue was extracted with ethyl acetate three times followed by washing with saturated aqueous sodium chloride. The solution was dried over sodium sulfate. The solvent was evaporated, and the crude peptide was precipitated in cold petroleum ether, centrifuged, and dried under reduced pressure. The obtained solid was dissolved in $4 \mathrm{M} \mathrm{HCl}$ in 1,4-dioxane $(5 \mathrm{~mL})$ at $0{ }^{\circ} \mathrm{C}$. After stirring for $1 \mathrm{~h}$ at r.t., the solution was concentrated under vacuum. Saturated aqueous sodium bicarbonate was 
added to the residue and extracted with ethyl acetate three times followed by washing the combined solution with saturated aqueous sodium chloride. The solution was dried over sodium sulfate and concentrated under reduced pressure. The obtained residue was purified over silica gel chromatography (dichloromethane:methanol $=100: 2$ to 100:10). The residue was dissolved in dichloromethane $(10 \mathrm{~mL})$, and $4 \mathrm{M} \mathrm{HCl}$ in 1,4-dioxane $(3 \mathrm{~mL})$ was added at $0{ }^{\circ} \mathrm{C}$. The precipitate was centrifuged and dried under reduced pressure to obtain the title compound $(2.40 \mathrm{~g}, 55.4 \%) .{ }^{1} \mathrm{H}$ NMR $\left(\mathrm{DMSO}_{-} d_{6}\right) \delta: 0.78(3 \mathrm{H}, \mathrm{d}, J=5.5 \mathrm{~Hz}), 0.81(3 \mathrm{H}, \mathrm{d}, J=$ $5.5 \mathrm{~Hz}), 1.33-1.42(2 \mathrm{H}, \mathrm{m}), 1.50-1.60(1 \mathrm{H}, \mathrm{m}), 1.65-1.73(1 \mathrm{H}, \mathrm{m}), 1.74-1.89$ (2H, m), 2.16 $-2.27(1 \mathrm{H}, \mathrm{m}), 3.10-3.26(4 \mathrm{H}, \mathrm{m}), 4.10-4.20(1 \mathrm{H}, \mathrm{m}), 4.40(1 \mathrm{H}, \mathrm{dd}, J=7.5,15.5 \mathrm{~Hz}), 4.58$ $(1 \mathrm{H}, \mathrm{dd}, J=7.0,14.5 \mathrm{~Hz}), 5.16(1 \mathrm{H}, \mathrm{d}, J=13.5 \mathrm{~Hz}), 5.24(1 \mathrm{H}, d, J=13.5 \mathrm{~Hz}), 6.96(1 \mathrm{H}, \mathrm{dd}$, $J=7.5,7.5 \mathrm{~Hz}), 7.05(1 \mathrm{H}, \mathrm{dd}, J=7.5,7.5 \mathrm{~Hz}), 7.20(1 \mathrm{H}, \mathrm{s}), 7.33(1 \mathrm{H}, \mathrm{d}, J=8.5 \mathrm{~Hz}), 7.47(1 \mathrm{H}$, $\mathrm{d}, J=8.0 \mathrm{~Hz}), 7.96(2 \mathrm{H}, \mathrm{s}), 8.07(1 \mathrm{H}, \mathrm{s}), 8.46(1 \mathrm{H}, \mathrm{bs}), 8.60-8.68(2 \mathrm{H}, \mathrm{m}), 9.98(1 \mathrm{H}, \mathrm{bs}), 10.93$ $(1 \mathrm{H}, \mathrm{s}) ; \mathrm{MS}(\mathrm{ESI}) 641(\mathrm{MH})^{+}$

\section{General Procedure for the Preparation of Peptides: H-Tyr-o-Ala-Gly-Phe-Xxx-Pro-Leu-Trp- 0-3,5-BzI $\left(\mathrm{CF}_{3}\right)_{2} \cdot \mathrm{TFA}(1-8)$}

$\mathrm{H}-\mathrm{Pro}-\mathrm{Leu}-\mathrm{Trp}-\mathrm{O}-3,5-\mathrm{Bzl}\left(\mathrm{CF}_{3}\right)_{2} \cdot \mathrm{HCl}$ was coupled stepwise with 1.1 equiv of Boc-Xxx-OH, Boc-Phe-OH, and Boc-Tyr- -Ala-Gly-OH using the standard PyBOP/HOBt procedure to afford crude H-Tyr-D-Ala-Gly-Phe-Xxx-Pro-Leu-Trp-O-3,5-Bzl $\left(\mathrm{CF}_{3}\right)_{2}$-TFA. In every coupling, PyBOP (1.2 equiv), HOBt (1.2 equiv), and NMM (2.2 equiv) were used in DMF. After the coupling was completed, saturated aqueous sodium bicarbonate was added to the solution and most of the organic solvent was removed under reduced pressure. The residue was extracted with ethyl acetate three times followed by washing with saturated aqueous sodium chloride. The solution was dried over sodium sulfate. The solvent was evaporated, and the crude peptide was precipitated in cold ether or cold petroleum ether, centrifuged, and dried under reduced pressure. The obtained $N^{\alpha}$-Boc-protected peptide was treated with $4 \mathrm{M} \mathrm{HCl}$ in 1,4-dioxane (for Boc-Xxx-OH and Boc-Phe-OH) or TFA (for Boc-Tyr-D-Ala-Gly-OH). After the deprotection was completed, the solution was concentrated and the crude peptide was precipitated in cold ether, centrifuged, and dried under reduced pressure. The yield of obtained crude peptides through this three couplings were as follows: H-Tyr-D-Ala-Gly-Phe-Phe-ProLeu-Trp-O-3,5-Bzl- $\left(\mathrm{CF}_{3}\right)_{2}$. TFA (1), 96\%; H-Tyr-d-Ala-Gly-Phe-d-Phe-Pro-Leu-Trp-O-3,5$\mathrm{Bzl}\left(\mathrm{CF}_{3}\right)_{2}$.TFA (2), 60\%; H-Tyr-d-Ala-Gly-Phe-Gly-Pro-Leu-Trp-O-3,5-Bzl $\left(\mathrm{CF}_{3}\right)_{2} \cdot \mathrm{TFA}$ (3), 66\%; H-Tyr-d-Ala-Gly-Phe-Leu-Pro-Leu-Trp-O-3,5-Bzl $\left(\mathrm{CF}_{3}\right)_{2} \cdot \mathrm{TFA}(4), 63 \%$; H-Tyr-d-AlaGly-Phe-Met-Pro-Leu-Trp-O-3,5-Bzl $\left(\mathrm{CF}_{3}\right)_{2}$.TFA (5), 61\%; H-Tyr-d-Ala-Gly-Phe-Met(O)Pro-Leu-Trp-O-3,5-Bzl $\left(\mathrm{CF}_{3}\right)_{2}$.TFA (6), 67\%; H-Tyr-d-Ala-Gly-Phe-Nle-Pro-Leu-Trp-O-3,5$\mathrm{Bzl}\left(\mathrm{CF}_{3}\right)_{2}$.TFA (7), 55\%; H-Tyr-d-Ala-Gly-Phe- $N$-Me-Nle-Pro-Leu-Trp-O-3,5-Bzl-

$\left(\mathrm{CF}_{3}\right)_{2} \cdot \mathrm{TFA}(7), 49 \%$. Pure peptides were obtained following RP-HPLC purification and then lyophilized.

\section{Characterization of Peptides}

Coupling and deprotection reactions were monitored by TLC. Preparative RP-HPLC was performed on Waters Delta Prep 4000 with Vydac 218 TP C-18 column $(22 \times 250 \mathrm{~mm}, 10-15$ $\mu \mathrm{m}, 42-57 \%$ of acetonitrile $)$ or Waters XTerra C-18 column $(19 \times 250 \mathrm{~mm}, 10 \mu \mathrm{m}, 40-60 \%$ of acetonitrile). The purified peptides were characterized by HRMS, TLC, analytical HPLC and ${ }^{1} \mathrm{H}-1 \mathrm{D}-\mathrm{NMR}$. Sequential assignment of proton resonances was achieved by $2 \mathrm{D}-\mathrm{TOCSY}$ NMR experiments. ${ }^{42-46}$ High-resolution mass spectra were taken in the positive ion mode using ESI methods at the University of Arizona Mass Spectrometry Facility. TLC was performed on aluminum sheets coated with a $0.2 \mathrm{~mm}$ layer of silica gel $60 \mathrm{~F}_{254}$ Merck using the following solvent systems: (1) $\mathrm{CHCl}_{3}: \mathrm{MeOH}: \mathrm{AcOH}=90: 10: 3$; (2) EtOAc: $n$-BuOH: water:AcOH 5:3:1:1; and (3) n-BuOH:water:AcOH = 4:1:1. TLC chromatograms were visualized by UV light and by ninhydrin spray followed by heating (hot plate). Analytical HPLC was performed on a Hewlett-Packard 1100 with Waters NOVA-Pak C-18 column (3.9 
$\times 150 \mathrm{~mm}, 5 \mu \mathrm{m}) .{ }^{1} \mathrm{H}-1 \mathrm{D}-\mathrm{NMR}$ spectra were recorded on a Bruker DRX-500 spectrometer. 2D-TOCSY NMR spectra were performed on a Bruker DRX-600 spectrometer equipped with a $5 \mathrm{~mm}$ Nalorac triple-resonance single-axis gradient probe. The NMR experiments were conducted in DMSO- $d_{6}$ solution at $298 \mathrm{~K}$. Spectra were referenced to residual solvent protons as $2.49 \mathrm{ppm}$. The processing of NMR data was performed with the XwinNmr software (Bruker BioSpin, Fremont, CA) and the Felix 2000 package (Accelrys Inc., San Diego, CA). In TOCSY experiments, the TPPI mode ${ }^{47}$ with MLEV-17 Mixing Sequence ${ }^{42}$ were used with a mixing time of $62.2 \mathrm{~ms}$, at a spin-lock field of $8.33 \mathrm{kHz}$. TOCSY spectra were acquired with $2 \mathrm{k}$ complex pairs in $\mathrm{t}_{2}$ and 750 FIDs using a $90^{\circ}$-shifted sine-squared window function in both dimensions.

\section{Cell Lines}

For opioid receptors, the cDNA for the human $\delta$ opioid receptor (DOR) was a gift from Dr. Brigitte Kieffer (IGBMC, Illkirch, France). The cDNA for the rat $\mu$ opioid receptor (MOR) was a gift from Dr. Huda Akil (University of Michigan, MI). Stable expression of the rat MOR (pCDNA3) and the human DOR (pCDNA3) in the neuroblastoma cell line, HN9.10, were achieved with the respective cDNAs by calcium phosphate precipitation followed by clonal selection in neomycin. Expression of the respective receptors was initially verified and the level of expression periodically monitored by radioligand saturation analysis (see below). All cells were maintained at $37{ }^{\circ} \mathrm{C}$, with a $95 \%$ air $/ 5 \% \mathrm{CO}_{2}$ humidified atmospherein a Forma Scientific incubator in Dulbecco's modified Eagle's medium (DMEM) with $10 \%$ bovine serum albumin (BSA) and $100 \mathrm{U} \mathrm{mL}$ penicillin/100 $\mu \mathrm{g} \mathrm{mL}$ streptomycin. For the NK1 receptor, the rNK1/CHO cell line was obtained from Dr. James Krause (University of Washington Medical School, St. Louis, MI). Expression of the receptor was verified as previously described by Krause. ${ }^{48}$ All cells were maintained at a $37^{\circ} \mathrm{C}, 95 \%$ air and $5 \% \mathrm{CO}_{2}$, humidified atmosphere, in a Forma Scientific incubator in Ham's F12 with 2.5 mM HEPES, $10 \%$ fetal bovine serum, and $100 \mathrm{U} / \mathrm{mL}$ penicillin, $100 \mu \mathrm{g} / \mathrm{mL}$ streptomycin and $500 \mu \mathrm{g} / \mathrm{mL}$ geneticin.

\section{Radioligand Labeled Binding Assays}

For opioid receptors, crude membranes were prepared as previously described ${ }^{49}$ from the transfected cells that express the rat MOR (rMOR) or the human DOR (hDOR). The protein concentration of the membrane preparations was determined by the Lowry method and the membranes were stored at $-80^{\circ} \mathrm{C}$ until use. Membranes were resuspended in assay buffer (50 $\mathrm{mM}$ Tris, $\mathrm{pH} 7.4$, containing $50 \mu \mathrm{g} / \mathrm{mL}$ bacitracin, $30 \mu \mathrm{M}$ bestatin, $10 \mu \mathrm{M}$ captopril, $100 \mu \mathrm{M}$ phenylmethylsulfonyl fluoride (PMSF), $1 \mathrm{mg} / \mathrm{mL}$ BSA). The dissociation constant $\left(K_{\mathrm{d}}\right)$ of tritiated [D-Ala, ${ }^{2}$ NMePhe, ${ }^{4}$ Gly ${ }^{5}$-ol]-enkephalin $\left(\left[{ }^{3} \mathrm{H}\right] \mathrm{DAMGO}\right)$ at the rMOR and that of tritiated c[D-Pen, ${ }^{2}$-Pen $\left.{ }^{5}\right]$-enkephalin $\left(\left[{ }^{3} \mathrm{H}\right]\right.$-DPDPE) at the hDOR were as previously described. ${ }^{20}$ For competition analysis, ten concentrations of a test compound were each incubated, in duplicates, with $50 \mu \mathrm{g}$ of membranes from rMOR or hDOR expressing cells and the $K_{\mathrm{d}}$ concentration of [ ${ }^{3} \mathrm{H}$ ]DAMGO $(1.0 \mathrm{nM}, 50 \mathrm{Ci} / \mathrm{mmol})$, or of [ $\left.{ }^{3} \mathrm{H}\right] \mathrm{DPDPE}(1.0 \mathrm{nM}, 44$ $\mathrm{Ci} / \mathrm{mmol})$, respectively. Naloxone $(10 \mu \mathrm{M})$ was used to define the nonspecific binding of the radioligands in all assays.. The samples were incubated in a shaking water bath at $25^{\circ} \mathrm{C}$ for 3 $\mathrm{h}$, followed by rapid filtration through Whatman Grade GF/B filter paper (Gaithersburg, MD) presoaked in $1 \%$ polyethyleneimine, washed four times each with $2 \mathrm{~mL}$ of cold saline. For the NK1 receptor, competition binding assays for the NK1 receptor were carried out on crude membranes prepared from transfected $\mathrm{CHO}$ cells expressing the rat NK1 receptor. Ten concentrations of a test compound were each incubated, in duplicates, with 50-100 $\mu \mathrm{g}$ of membrane homogenate and $0.3-0.4 \mathrm{nM}\left[{ }^{3} \mathrm{H}\right]$ substance $\mathrm{P}(135 \mathrm{Ci} / \mathrm{mmol}$, Perkin-Elmer $)$ in 1 $\mathrm{mL}$ final volume of assay buffer (50 mM Tris, $\mathrm{pH} 7.4$, containing $5 \mathrm{mM} \mathrm{MgCl}_{2}, 50 \mu \mathrm{g} / \mathrm{mL}$ bacitracin, $30 \mu \mathrm{M}$ bestatin, $10 \mu \mathrm{M}$ captopril, $100 \mu \mathrm{M}$ phenylmethylsulfonyl fluoride (PMSF) at $25^{\circ} \mathrm{C}$ for $20 \mathrm{~min}$. Substance $\mathrm{P}$ at $10 \mu \mathrm{M}$ was used to define the nonspecific binding. Membrane concentrations used in the assay were within the tissue linearity range. The $\left[{ }^{3} \mathrm{H}\right]$ 
substance $\mathrm{P}$ concentration was selected based on the saturation binding experiments which showed a high affinity binding with $K_{\mathrm{d}}=0.16 \pm 0.03 \mathrm{nM}$. The incubation times correspond to the binding equilibrium as determined from the kinetics experiments. The reaction was terminated by rapid filtration and washed as described above. The filter-bound radioactivity was measured by liquid scintillation counting (Beckman LS 6000SC). Log $\mathrm{IC}_{50}$ value for each test compound was determined from nonlinear regression analysis of data collected from two independent experiments performed in duplicates (40 independent experimental values) using GraphPad Prizm 4 software (GraphPad, San Diego, CA). The inhibition constant, $K_{\mathrm{i}}$, was calculated from the antilogarithmic $\mathrm{IC}_{50}$ value by the Cheng and Prusoff equation.

\section{[35S]GTPYS Binding Assay}

The method was carried out as previously described. ${ }^{49}$ Membrane from transfected rMOR or hDOR cells $(10 \mu \mathrm{g})$ in a final volume of $1 \mathrm{~mL}$ reaction mix (50 mM HEPES, pH 7.4, $1 \mathrm{mM}$ EDTA, $5 \mathrm{mM} \mathrm{MgCl}_{2}, 30 \mu \mathrm{M}$ GDP, $1 \mathrm{mM}$ dithiothreitol, $100 \mathrm{mM} \mathrm{NaCl}, 0.1 \mathrm{mM}$ PMSF, $0.1 \%$ BSA, $0.1 \mathrm{nM}\left[{ }^{35} \mathrm{~S}\right] \mathrm{GTP} \gamma \mathrm{S}$ ) was incubated with various concentrations of the test drug, in duplicates, for $90 \mathrm{~min}$ at $30^{\circ} \mathrm{C}$ in a shaking water bath. Reactions were terminated by rapid filtration through Whatman GF/B filters (presoaked in water), followed by four washes with $4 \mathrm{~mL}$ of ice-cold wash buffer ( $50 \mathrm{mM}$ Tris, $5 \mathrm{mM} \mathrm{MgCl}_{2}, 100 \mathrm{mM} \mathrm{NaCl}, \mathrm{pH}$ 7.4). The radioactivity was determined by liquid scintillation counting as above. Basal level of $\left[{ }^{35} \mathrm{~S}\right]$ GTP $\gamma \mathrm{S}$ binding was defined as the amount bound in the absence of any test drug. Nonspecific binding was determined in the presence of $10 \mu \mathrm{M}$ unlabeled GTP $\gamma$ S. Total binding was defined as the amount of radioactivity bound in the presence of test drug. The effect of the drug at each concentration on $\left[{ }^{35} \mathrm{~S}\right] \mathrm{GTP} \gamma \mathrm{S}$ binding was calculated as a percentage by the following equation: [total bound - basal]/ [basal - nonspecific] $\times 100$. Data were analyzed by nonlinear least-squares regression analysis using GraphPad Prism4 using data collected from two independent experiments. The $\mathrm{EC}_{50}$ for a test drug is converted from the logarithmic $\mathrm{EC}_{50}$ value derived from the best fit curve, and the maximum stimulatory effect is expressed as $E_{\max } \pm$ standard error

For both radioligand and $\left[{ }^{35} \mathrm{~S}\right] \mathrm{GTP} \gamma \mathrm{S}$ binding, we adopted two independent experiments as our standard procedure for the initial evaluation of all compounds using cell lines because of the large number of compounds that we routinely screen, each compound typically on multiple receptor types, to determine both affinity and biological activity. These initial analyses were designed to identify trends of structure-activity relationship as rapidly as possible and were not intended for determining geometric mean values of $K_{\mathrm{i}}$ or $\mathrm{EC}_{50}$. The data pooled from two independent experiments indicated that the data are reproducible.

\section{Guinea Pig Isolated lleum Assay}

The in vitro tissue bioassays were performed as described previously. ${ }^{18,20,35,36}$ Male Hartley guinea pigs under $\mathrm{CO}_{2}$ anesthesia were sacrificed by decapitation, a nonterminal portion of the ileum removed, and the longitudinal muscle with myenteric plexus (LMMP) was carefully separated from the circular muscle as described previously. ${ }^{50}$ These tissues were tied to gold chains with suture silk and mounted between platinum wire electrodes in $20 \mathrm{~mL}$ organ baths at a tension of $1 \mathrm{~g}$ and bathed in oxygenated $\left(95: 5 \mathrm{O}_{2}: \mathrm{CO}_{2}\right) \mathrm{Kreb}$ 's bicarbonate buffer at $37^{\circ}$ $\mathrm{C}$ and stimulated electrically $(0.1 \mathrm{~Hz}, 0.4 \mathrm{~ms}$ duration $)$ at supramaximal voltage. Following an equilibration period, compounds were added cumulatively to the bath in volumes of 14-60 $\mu \mathrm{L}$ until maximum inhibition was reached. A baseline PL-017 was constructed to determine tissue integrity and allow calculation of antagonist activity before opioid analogue testing began. If no agonist activity was observed at $1 \mu \mathrm{M}$, a repeat PL-017 dose-response curve was constructed to test for opioid antagonist qualities. 
All testings for substance P antagonist activities were performed in the presence of $1 \mu \mathrm{M}$ naloxone to block opioid effects on the tissue. Two minutes after naloxone was added to the bath, the test peptide was added. Four minutes after naloxone was added, the test dose of substance $\mathrm{P}$ was added to the bath, the peak height was noted, and the tissues were washed. Possible agonist activity of the analogue also was observed during this period. Testing stopped at $1 \mathrm{mM}$ concentrations of the test compound.

\section{Mouse Isolated Vas Deferens (MVD) Assay}

The in vitro tissue bioassay was performed as described previously. ${ }^{18,20,35,36}$ Male ICR mice under $\mathrm{CO}_{2}$ anesthesia were sacrificed by cervical dislocation, and the vasa deferentia was removed. Tissues were tied to gold chains with suture silk and mounted between platinum wire electrodes in $20 \mathrm{~mL}$ organ baths at a tension of $0.5 \mathrm{~g}$ and bathed in oxygenated (95:5 $\left.\mathrm{O}_{2}: \mathrm{CO}_{2}\right)$ magnesium free Kreb's buffer at $37{ }^{\circ} \mathrm{C}$ and stimulated electrically $(0.1 \mathrm{~Hz}$, single pulses, $2.0 \mathrm{~ms}$ duration) at supramaximal voltage as previously described. ${ }^{51}$ Following an equilibration period, compounds were added to the bath cumulatively in volumes of 14-60 $\mu \mathrm{L}$ until maximum inhibition was reached. Response to an $\mathrm{IC}_{50}$ dose of DPDPE $(10 \mathrm{nM})$ was measured to determine tissue integrity before test compound testing.

\section{Analysis of the GPI and MVD assays}

For opioid data analysis, percentage inhibition was calculated using the average tissue contraction height for 1 min preceding the addition of the agonist divided by the contraction height $3 \mathrm{~min}$ after exposure to the dose of agonist. $\mathrm{IC}_{50}$ values represent the mean of not less than four tissues. $\mathrm{IC}_{50}$ and $E_{\max }$ estimates were determined by computerized nonlinear leastsquares analysis (the pharmacological statistics package FlashCalc: Dr. Michael Ossipov, University of Arizona, Tucson, AZ). For substance P data analysis, the height of the maximum peak produced during the control substance $\mathrm{P}$ dose-response curve was used as a $100 \%$ response and other values calculated as a percentage. $K_{\mathrm{e}}$ values represent the mean of not less than four tissues and were determined by computerized nonlinear least-squares analysis (FlashCalc).

\section{Acknowledgment}

The work was supported by grants from the USDHS, National Institute on Drug Abuse, DA-13449 and DA-06284. We thank Dr. Neil E. Jacobsen for assistance with the NMR measurements and the University of Arizona Mass Spectrometry Facility with the mass spectra measurements. We express appreciation for Ms. Margie Colie for assistance with the manuscript.

\section{References}

1. Yaksh TL. Spinal opiate analgesia: characteristics and principles of action. Pain 1981;11:293-346. [PubMed: 6276842]

2. Hill R. NK1 (substance P) receptor antagonists - why are they not analgesic in humans? Trends Pharmacol. Sci 2000;21:244-246. [PubMed: 10871891]

3. Kalso E. Improving opioid effectiveness: from ideas to evidence. Eur. J. Pain 2005;9:131-135. [PubMed: 15737801]

4. Khasabov SG, Rogers SD, Ghilardi JR, Peters CM, Mantyh PW, Simone DA. Spinal neurons that possess the substance $\mathrm{P}$ receptor are required for the development of central sensitization. J. Neurosci 2002;22:9086-9098. [PubMed: 12388616]

5. Mantyh PW, Allen CJ, Ghilardi JR, Rogers SD, Mantyh CR, Liu H, Basbaum AI, Vigna SR, Maggio JE. Rapid endocytosis of a $G$ protein coupled receptor: substance $P$ evoked internalization of its receptor in the rat striatum in vivo. Proc. Natl. Acad. Sci. U.S.A 1995;92:2622-2626. [PubMed: 7535928]

6. Moochhala SM, Sawynok J. Hyperalgesia produced by intrathecal substance P and related peptides: desensitization and cross desensitization. Br. J. Pharmacol 1984;82:381-388. [PubMed: 6203593] 
7. Nichols ML, Allen BJ, Rogers SD, Ghilardi JR, Honore P, Luger NM, Finke MP, Li J, Lappi DA, Simone DA, Mantyh PW. Transmission of chronic nociception by spinal neurons expressing the substance P receptor. Science 1999;286:1558-1561. [PubMed: 10567262]

8. King T, Gardell LR, Wang R, Vardanyan A, Ossipov MH, Malan TP Jr. Vanderah TW, Hunt SP, Hruby VJ, Lai J, Porreca F. Role of NK-1 neurotransmission in opioid-induced hyperalgesia. Pain 2005;116(3):276-288. [PubMed: 15964684]

9. King T, Ossipov MH, Vanderah TW, Porreca F, Lai J. Is paradoxical pain induced by sustained opioid exposure an underlying mechanism of opioid antinociceptive tolerance? Neurosignals 2005;14(4): 194-205. [PubMed: 16215302]

10. Ma W, Zheng WH, Kar S, Quirion R. Morphine treatment induced calcitonin gene-related peptide and substance P increases in cultured dorsal root ganglion neurons. Neuroscience 2000;99(3):529_ 539. [PubMed: 11029544]

11. Powell KJ, Quirion R, Jhamandas K. Inhibition of neurokinin-1-substance P receptor and prostanoid activity prevents and reverses the development of morphine tolerance in vivo and the morphineinduced increase in CGRP expression in cultured dorsal root ganglion neurons. Eur. J. Neurosci 2003;18(6):1572-1583. [PubMed: 14511336]

12. Misterek K, Maszczynska I, Dorociak A, Gumulka SW, Carr DB, Szyfelbein SK, Lipkowski AW. Spinal co-administration of peptide substance $\mathrm{P}$ antagonist increases antinociceptive effect of the opioid peptide biphalin. Life Sci 1994;54(14):939-944. [PubMed: 7511201]

13. Gu G, Kondo I, Hua XY, Yaksh TL. Resting and evoked spinal substance P release during chronic intrathecal morphine infusion: parallels with tolerance and dependence. J. Pharmacol. Exp. Ther 2005;314(3):1362-1369. [PubMed: 15908510]

14. Hokfelt T, Kellereth JO, Nilsson G. Immunohistochemical studies on the localization and distribution of substance P in cat primary sensory neurons. Brain Res 1975;100:235-252. [PubMed: 1104079]

15. Marchand, JE.; Kream, RM. Substance P and Related Peptides: Cellular and Molecular Physiology. New York Academy of Science; New York: 1990. Substance P and Somatostatin levels in rhumatioid arthesis, molecular physiology.; p. 437-438.

16. Kondo I, Marvizon JC, Song B, Salgado F, Codeluppi S, Hua XY, Yaksh TL. Inhibition by spinal mu- and delta-opioid agonists of afferent-evoked substance P release. J. Neurosci 2005;25(14):36513660. [PubMed: 15814796]

17. Slaninova J, Knapp RJ, Wu J, Fang SN, Kramer T, Hruby VJ, Yamamura HI. Opioid receptor binding properties of analgesic analogues of cholecystokinin octapeptide. Eur. J. Pharmacol 1991;200:195198. [PubMed: 1663041]

18. Lee YS, Agnes RS, Badghisi H, Davis P, Ma SW, Lai J, Porreca F, Hruby VJ. Design and synthesis of novel hydrazide-linked bifunctional peptides as delta/mu opioid receptor agonists and CCK-1/ CCK-2 receptor antagonists. J. Med. Chem 2006;49(5):1773-1780. [PubMed: 16509592]

19. Hruby VJ, Agnes RS, Davis P, Ma SW, Lee YS, Vanderah TW, Lai J, Porreca F. Design of novel peptide ligands which have opioid agonist activity and CCK antagonist activity for the treatment of pain. Life Sci 2003;73(6):699-704. [PubMed: 12801591]

20. Agnes RS, Lee YS, Davis P, Ma SW, Badghisi H, Porreca F, Lai J, Hruby VJ. Structure-activity relationships of bifunctional peptides based on overlapping pharmacophores at opioid and cholecystokinin receptors. J. Med. Chem 2006;49(10):2868-2875. [PubMed: 16686530]

21. Bonney IM, Foran SE, Marchand JE, Lipkowski AW, Carr DB. Spinal antinociceptive effects of AA501, a novel chimeric peptide with opioid receptor agonist and tachykinin receptor antagonist moieties. Eur. J. Pharmacol 2004;488(1-3):91-99. [PubMed: 15044040]

22. Sakurada T, Yuhki M, Inoue M, Sakurada C, Tan-No K, Ohba M, Kisara K, Sakurada S. Opioid activity of sendide, a tachykinin NK1 receptor antagonist. Eur. J. Pharmacol 1999;369(3):261-266. [PubMed: 10225361]

23. Kosson P, Bonney I, Carr DB, Lipkowski AW. Endomorphins interact with tachykinin receptors. Peptides 2005;26(9):1667-1669. [PubMed: 16112408]

24. Gentilucci L. New Torends in the Development of Opioid Peptide Analogues as Advanced Remedies for pain Relief. Curr. Topics Med. Chem 2004;4:19-38.

25. Rapaka RS, Porreca F. Development of delta opioid peptides as nonaddicting analgesics. Pharm. Res 1991;8(1):1-8. [PubMed: 1849640] 
26. Dondio G, Ronzoni S, Petrillo P. Non-peptide $\delta$ opioid agonists and antagonists. Expert Opin. Ther. Pat 1997;7:1075-1098.

27. Bilsky EJ, Calderon SN, Wang T, Bernstein RN, Davis P, Hruby VJ, McNutt RW, Rothman RB, Rice KC, Porreca F. SNC 80, a selective, nonpeptidic and systemically active opioid delta agonist. J. Pharmacol. Exp. Ther 1995;273:359-366. [PubMed: 7714789]

28. Quock RM, Burkey TH, Varga E, Hosohata Y, Hosohata K, Cowell SM, Slate CA, Ehlert FJ, Roeske WR, Yamamura HI. The delta-opioid receptor: molecular pharmacology, signal transduction, and the determination of drug efficacy. Pharmacol. Rev 1999;51(3):503-532. [PubMed: 10471416]

29. Shimohigashi Y. Design Principles: Enkephalins With Predictable Mu/Delta Receptor Specificity. NIDA Res. Monogr 1986;69:65-100. [PubMed: 3020418]

30. Horan PJ, Mattia A, Bilsky EJ, Weber S, Davis TP, Yamamura HJ, Malatynska E, Appleyard SM, Slaninova J, Misicka A, Lipowski AW, Hruby VJ, Porreca F. Antinociceptive Profile of Biphalin, a Dimeric Enkephalin Analog. J. Pharmacol. Exp. Ther 1993;265:1446-1454. [PubMed: 8389867]

31. Macleod AM, Merchant KJ, Cascieri MA, Sadowski S, Ber E, Swain CJ, Baker R. N-Acyl-1tryptophan benzyl esters: potent substance P receptor antagonists. J. Med Chem 1993;14:2044-2045. [PubMed: 8393115]

32. Cascieri MA, Macleod AM, Underwood D, Shiao LL, Ber E, Sadowski S, Yu H, Merchant KJ, Swain CJ, Strader CD, Fong TM. Characterization of the interaction of N-acyl-L-tryptophan benzyl ester neurokinin antagonists with the human neurokinin-1 receptor. J. Biol. Chem 1994;269(9):65876591. [PubMed: 7509807]

33. Millet R, Goossens L, Goossens JF, Chavatte P, Bertrand-Caumont K, Houssin R, Henichart JP. Conformation of the tripeptide Cbz-Pro-Leu-Trp-OBzl(CF3) 2 deduced from two-dimensional $1 \mathrm{H}-$ NMR and conformational energy calculations is related to its affinity for NK1-receptor. J. Pept. Sci 2001;7(6):323-330. [PubMed: 11461046]

34. Millet R, Goossens L, Bertrand-Caumont K, Chavatte P, Houssin R, Henichart JP. Synthesis and biological evaluation of tripeptide derivatives of Cbz-Gly-Leu-Trp-OBzl(CF3) 2 as NK1/NK2 ligands. Lett. Pep. Sci 1999;6:255-262.

35. Polt R, Porreca F, Szabo LZ, Bilsky EJ, Davis P, Abbruscato TJ, Davis TP, Horvath R, Yamamura HI, Hruby VJ. Glycopeptide enkephalin analogues produce analgesia in mice: evidence for penetration of the blood-brain barrier. Proc. Natl. Acad. Sci. U.S.A 1994;91(15):7114-7118. [PubMed: 8041755]

36. Misicka A, Lipkowski AW, Horvath R, Davis P, Kramer TH, Yamamura HI, Hruby VJ. Topographical requirements for delta opioid ligands: common structural features of dermenkephalin and deltorphin. Life Sci 1992;51(13):1025-1032. [PubMed: 1326067]

37. Lord JAH, Waterfield AA, Hughes J, Kosterlitz HW. Endogenous opioid peptides: multiple agonists and receptors. Nature 1977;207:495-499. [PubMed: 195217]

38. Kiritsy-Roy JA, Chan SK, Iwamoto ET. Methionine oxidation enhances opioid activity of an enkephalin analog. Life Sci 1983;32(8):889-893. [PubMed: 6131372]

39. Glavin GB, Pinsky C, Hall AM. Effects of metkephamid (LY127623), a selective delta opioid receptor agonist, on gastric function. Life Sci 1990;46(15):1075-1079. [PubMed: 2159095]

40. Burkhardt C, Frederickson RC, Pasternak GW. Metkephamid (Tyr-D-ala-Gly-Phe-N(Me)Met-NH2), a potent opioid peptide: receptor binding and analgesic properties. Peptides 1982;3(5):869-871. [PubMed: 6294639]

41. Frederickson RC, Smithwick EL, Shuman R, Bemis KG. Metkephamid, a systemically active analog of methionine enkephalin with potent opioid alpha-receptor activity. Science 1981;211:603-605. [PubMed: 6256856]

42. Braunschweiler L, Ernst RR. Coherence transfer by isotropic mixing: Application to proton correlation spectroscopy. J. Magn. Reson 1983;53:521-528.

43. Davis DG, Bax A. Assignment of complex 1H-NMR spectra via two-dimensional homonuclear Hartmann-Hahn spectroscopy. J. Am Chem. Soc 1985;107:2820-2821.

44. Subramanian S, Bax A. Generation of pure phase NMR subspectra for measurement of homonuclear coupling constants. J. Magn. Reson 1987;71:325-330.

45. Rance M. Improved techniques for homonuclear rotating-frame and isotropic mixing experiments. J. Magn. Reson 1987;74:557-564. 
46. Bax A, Davis DG. MLEV-17-based two-dimensional homonuclear magnetization transfer spectroscopy. J. Magn. Reson 1985;65:355-360.

47. Marion D, Wuthrich K. Application of phase sensitive two-dimensional correlated spectroscopy (COSY) for measurements of $1 \mathrm{H}-1 \mathrm{H}$ spin-spin coupling constants in proteins. Biochem. Biophys. Res. Commun 1983;113:967-974. [PubMed: 6307308]

48. Boyd ND, Kage R, Dumas JJ, Krause JE, Leeman SE. The peptide binding site of the substance P (NK-1) receptor localized by a photoreactive analogue of substance P: presence of a disulfide bond. Proc. Natl. Acad. Sci. U.S.A 1996;93:433-437. [PubMed: 8552654]

49. Lorenzen A, Fuss M, Vogt H, Schwabe U. Measurement of guanine nucleotide-binding protein activation by $\mathrm{A} 1$ adenosine receptor agonists in bovine brain membranes: stimulation of guanosine-5'-O-(3-[35S]thio)triphosphate binding. Mol. Pharmacol 1993;44(1):115-123. [PubMed: 8341267]

50. Porreca F, Burks TF. Affinity of normorphine for its pharmacologic receptor in the naive and morphine-tolerant guinea-pig isolated ileum. J. Pharmacol. Exp. Ther 1983;225(3):688-693. [PubMed: 6306216]

51. Porreca F, LoPresti D, Ward SJ. Opioid agonist affinity in the guinea-pig ileum and mouse vas deferens. Eur. J. Pharmacol 1990;179(1-2):129-139. [PubMed: 2163849]

52. Lipkowski AW, Misicka A, Davis P, Stropova D, Janders J, Lachwa M, Porreca F, Yamamura HI, Hruby VJ. Biological activity of fragments and analogues of the potent dimeric opioid peptide, biphalin. Bioorg. Med. Chem. Lett 1999;9(18):2763-6. [PubMed: 10509931]

53. Akiyama K, Gee KW, Mosberg HI, Hruby VJ, Yamamura HI. Characterization of [3H][2-D\{penicillamine,5-D-p\}enicillamine]-enkephalin Binding to delta Opiate Receptors in the Rat Brain and Neuroblastoma-Glioma Hybrid Cell Line (NG 108-15). Proc. Natl. Acad. Sci. U.S.A 1985;82:2543-2547. [PubMed: 2986120]

54. Mosberg HI, Hurst MR, Hruby VJ, Gee HK, Yamamura HI, Galligan JJ, Burks TF. Bis-Penicillamine Enkephalins Possess Highly Improved Specificity toward delta Receptors. Proc. Natl. Acad. Sci. U.S.A 1983;80:5871-5874. [PubMed: 6310598]

55. Mosberg HI, Hurst R, Hruby VJ, Gee K, Akiyama K, Yamamura HI, Galligan JJ, Burks TF. Cyclic penicillamine containing enkephalin analogs display profound delta receptor selectivities. Life Sci 1983;33(Suppl 1):447-50. [PubMed: 6319901]

56. Yamamoto, T.; Nair, P.; Davis, P.; Ma, S-W.; Moye, S.; Largent, T.; Vanderah, TW.; Lai, J.; Porreca, F.; Yamamura, HI.; Hruby, VJ. Design, Structure-Activity Relationships and Biological Evaluation of Novel Bifunctional C-terminal Modified Peptides for delta/mu Opioid Receptor Agonists and Neurokinin-1 Receptor Antagonists.. American Chemical Society, 232nd National Meeting; San Francisco, CA. Sep. 10-14, 2006; p MEDI-7

\section{Supplementary Material}

Refer to Web version on PubMed Central for supplementary material. 


\section{DADLE H-Tyr'-D-ARa-GIY'-Phê-D-Leư ${ }^{5}$}

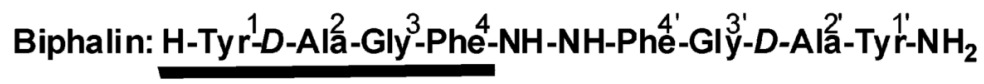

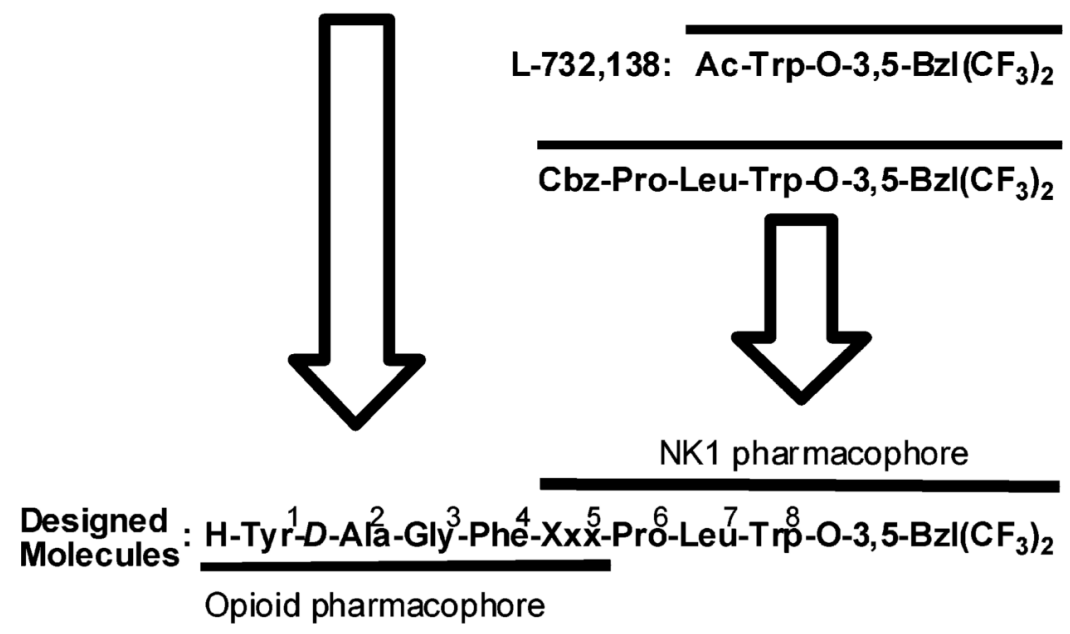

Xxx = Phe, D-Phe, Gly, Leu, Met, Met(O), Nle and N-Me-Nle

Figure 1.

Design of bifunctional peptides possessing sequences for both $\delta / \mu$ opioid agonist and neurokinin-1 antagonist. 


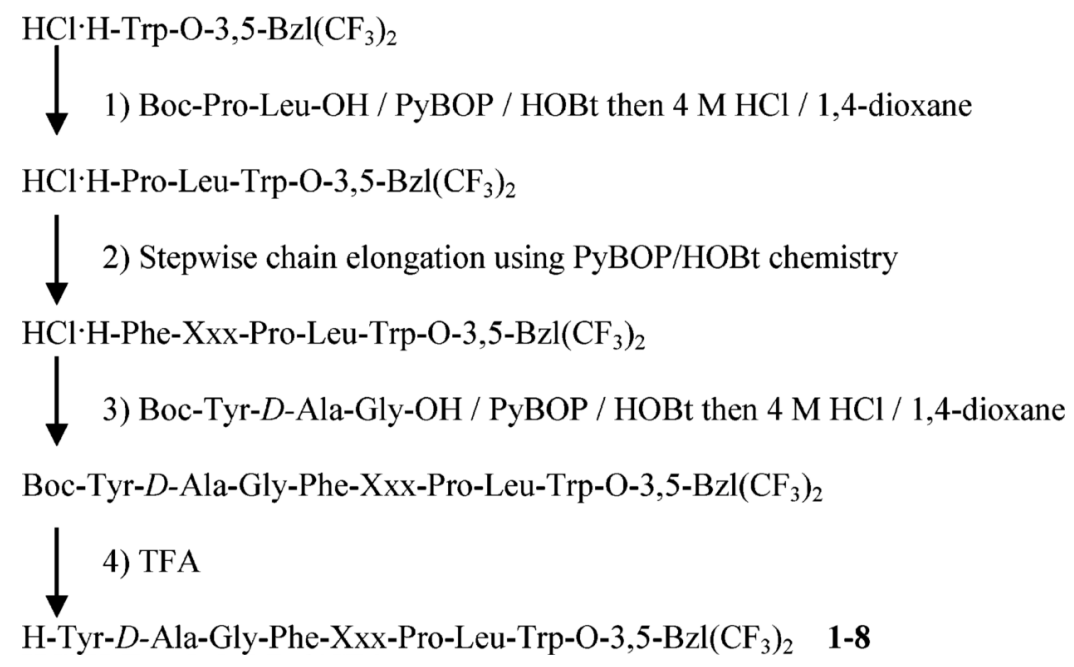

Figure 2.

Synthesis of bifunctional peptides. 


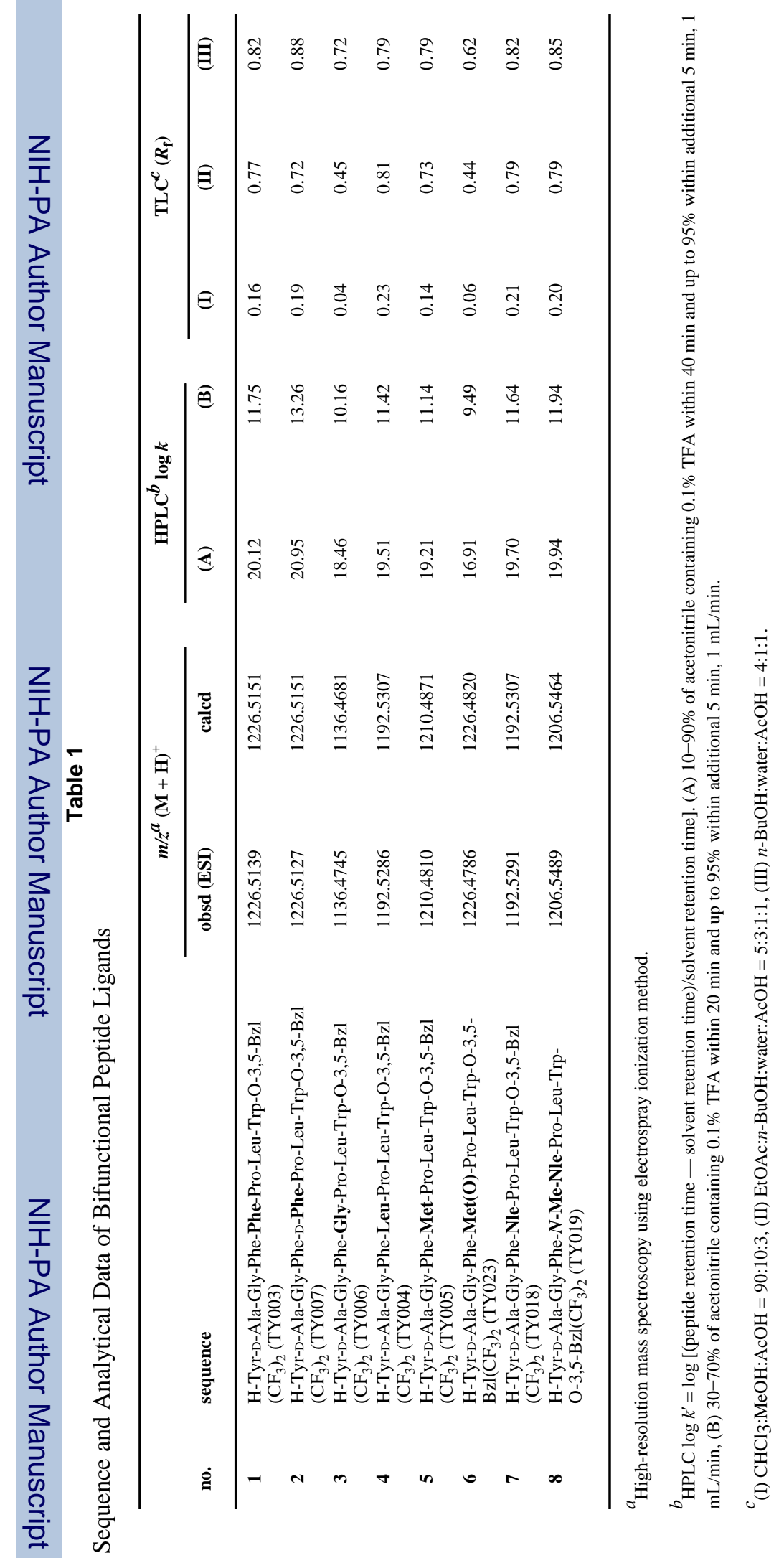




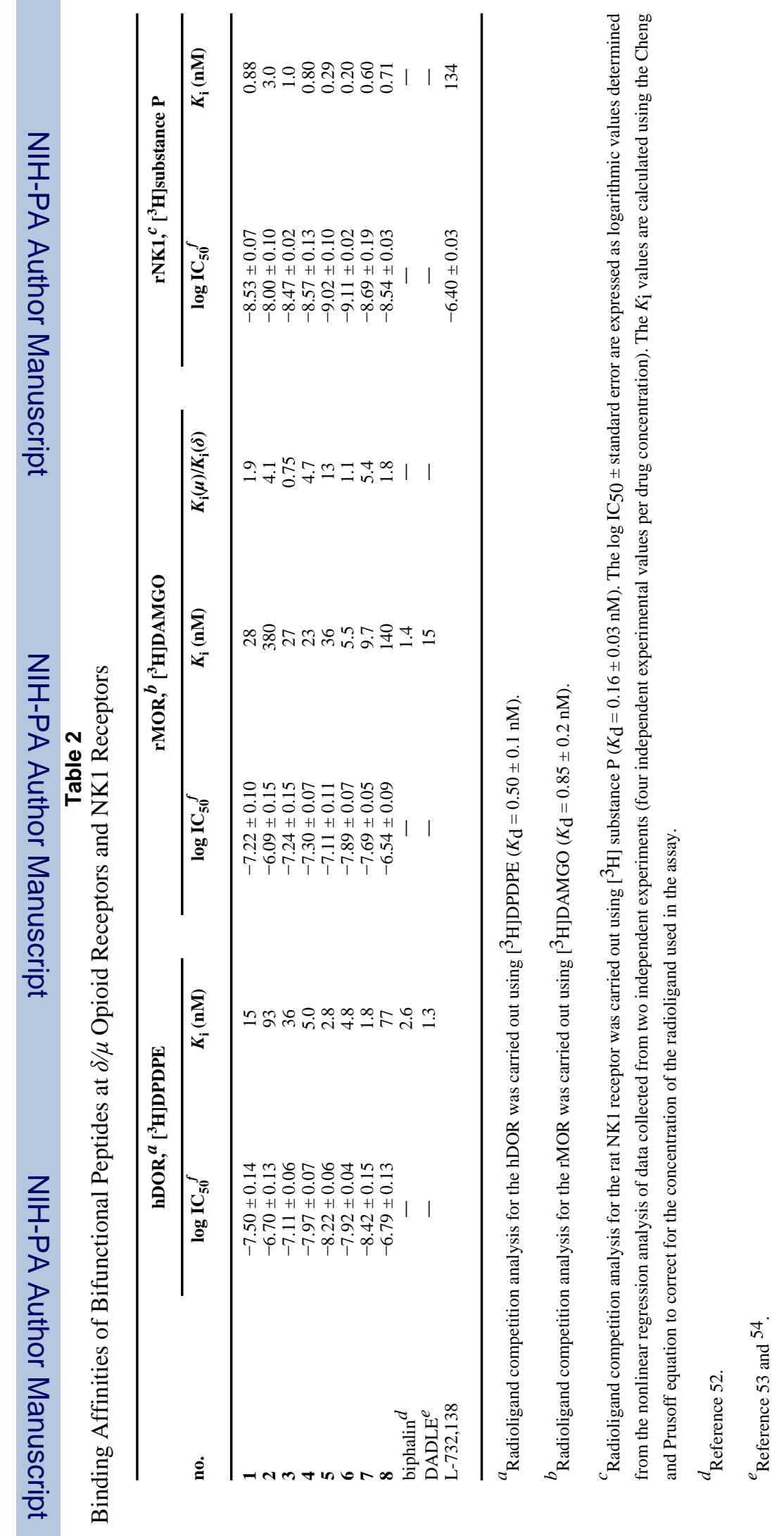




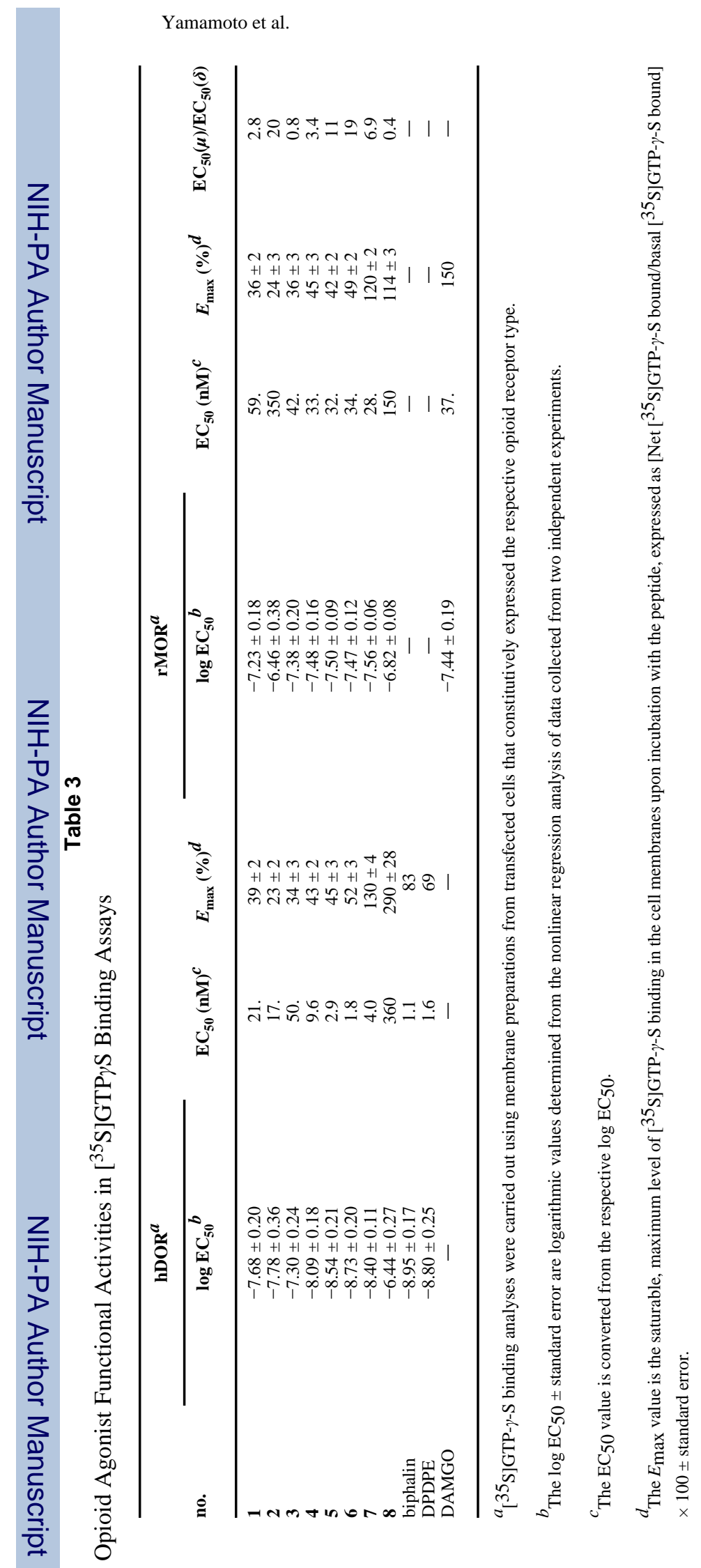

Page 17 


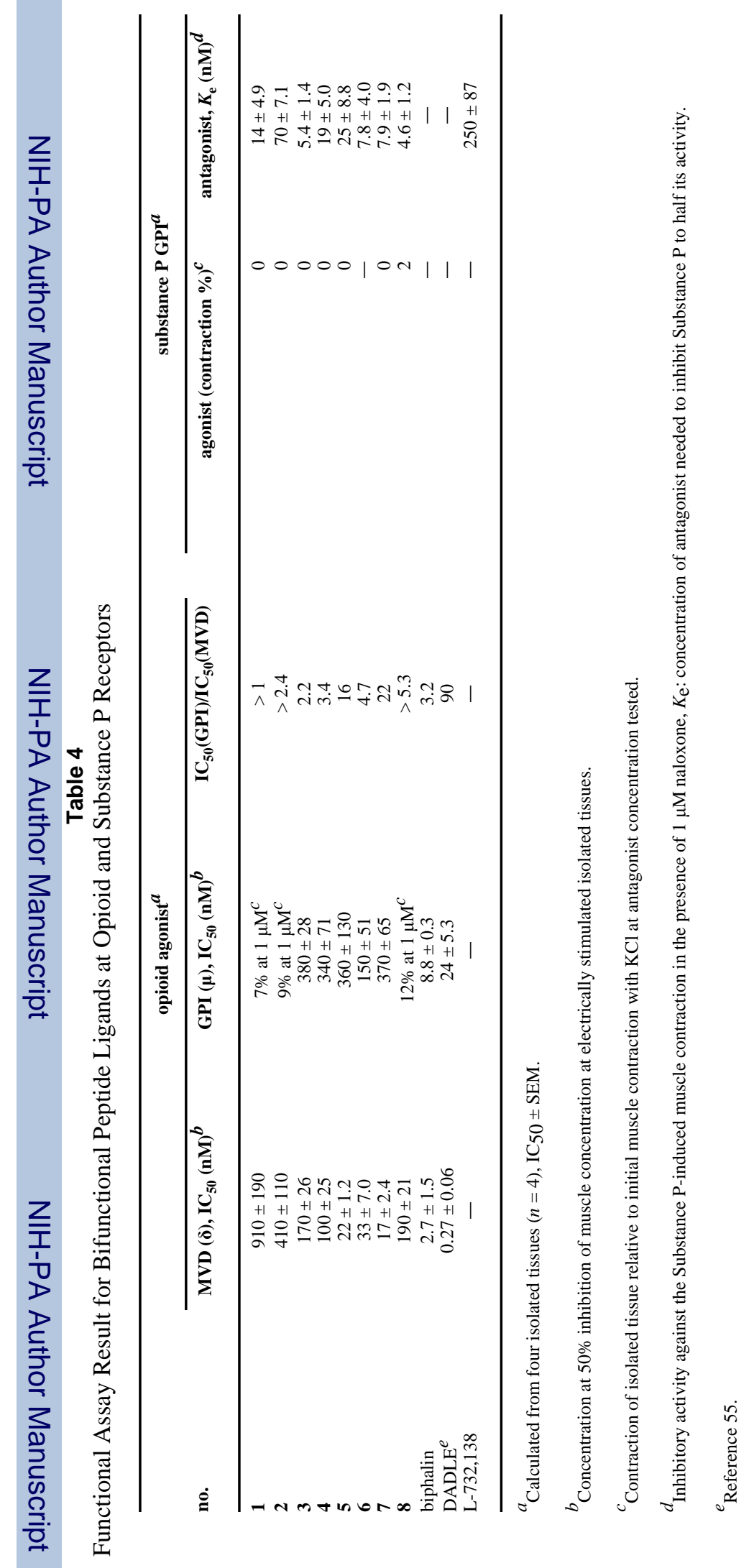

